\title{
Teachers Trainees and Metacognitive Strategies
}

\author{
Soumyabrata Mahapatra ${ }^{1}$, Dadhi Baman Tali ${ }^{2}$ and Ashok Dansana ${ }^{2 *}$
}

${ }^{1}$ Lecturer, Department of Education, Tezpur University, Assam, India

${ }^{2}$ Assistant Professor, School of Education, Ravenshaw University, Cuttack, Odisha, India

*Correspondence author: dansana.cie@gmail.com

Received: $14-05-2021$

Revised: $17-07-2021$

Accepted: 10-08-2021

\begin{abstract}
Metacognition and Learning styles are significant factors that influence learning. Learners exhibit different learning styles that influence the way they make sense of the learning experiences. Metacognitive strategies are the set of some executive techniques of cognition which are consciously used by learners to achieve a specific learning purpose. The present study has made an attempt to explore the relationship among Learning Styles and Metacognitive Strategies of Teacher Trainees and determine the Learning Styles as positive predictor and contributor for Metacognitive Strategies of Teacher Trainees during their training programme. The data have been collected by using random sampling techniques, through administered the tools, Metacognitive Strategies scale, (self-made) and Learning styles Questionnaire (Developed and standardized by Peter Honey and Alan Mumford (1986) from 120 teacher Trainees from four teacher training Institutions affiliated to different universities of Odisha and recognized by NCTE. The collected data were analyzed using Product moment coefficient of correlation (r) and Regression analysis. The results of the study reveal that metacognitive strategies metacognitive strategies of teacher trainees are positively related with their Activist, Reflector, Theorist, Pragmatist Learning Styles, further, Theorist and Reflector learning styles are the strong predictors and contributors of planning, monitoring and evaluation Metacognitive strategy, and Theorist and Pragmatist learning styles are the strong predictors and contributors of Organizing Metacognitive strategy of teacher trainees of teacher trainees.
\end{abstract}

Keywords: Metacognitive Strategies, Teacher Trainees

The value of education does not lie only in acquiring knowledge but rather in developing thinking abilities therefore, in today's information age, thinking skills are viewed as crucial for educated persons to cope with a rapidly changing world. This thinking could be unproductive without cognitive theory that is used to resolve doubt about what to do, how to do, how to organize, how to achieve, what to believe, or what to desire or seek. Thinking about what to believe, what to desire are the part of learning process, and how to do is the part of cognition and metacognition.

The nature of learning or knowing and nature of thinking are both area of interest with in the theories of educational psychology. However, these concepts do not occupy the same place in both fields. Theories of learning cover the area of how human learns using different styles of learning and how human think, how to do plan to achieve the learning outcomes, what are the strategies need to implement these styles of learning are the area of metacognition, an emerged cognitive theory. In this contrast, the researcher attempted to study on Learning styles i.e. Activist, Reflector, Theorist and Pragmatist with Metacognitive Strategies i.e. Planning, Organizing, Monitoring and Evaluation.

\section{Rationale of the Study}

Learning styles and metacognitive strategies are

How to cite this article: Mahapatra, S., Tali, D.B. and Dansana, A. (2021). Teachers Trainees and Metacognitive Strategies. Educational Quest: An Int. J. Edu. Appl. Soc. Sci., 12(2): 95-99.

Source of Support: None; Conflict of Interest: None (C) 
the important factors which affect the learners learning process. Peoples learn in various ways, by seeing, hearing, analyzing, visualizing, thinking, memorizing, reasoning etc. Thus, each individual in the process of learning has his/her own unique characteristics known as learning styles which determine in which way the people perceive information and understand the phenomena. On the other hand, Metacognitive strategies are plans or techniques which are consciously used by learners to achieve a specific purpose by implementing effectively these styles of learning or solve a problem or task. In other words, these are some techniques or devices used by the learners in order to acquire knowledge (Rubin, 1975). According to Oxford and Nyikos (1989), language learners tend to use those strategies which reflect their learning styles. Brown (2007), in the same vein, points out that, learning strategies do not operate by themselves, but rather are directly linked to learners' innate learning style and other personality-related factors. Therefore, the ways in which learner process information affect strategies which they select. If the metacognitive strategies do not match learners' learning styles, learners cannot have a good performance on learning.

After review the related literature it is revealed that the maximum number of studies have been conducted across the world on the area of metacognitive strategies which correlates with the learners' academic achievement, personality factors, self-efficacy and on another cognitive phenomenon and very few number of studies are found in India in relation to studies in abroad as founded by investigator. Above studies (Dales, and Gaylo, 2017; Sawhney, and Bansal, 2015; Tok, Ozgan, and Dos, 2014; Doganay, and Demir, 2011; Nagoziibe, 2009; Ozsoy, Memis, and Temur, 2009; Ozsoy, and Ataman, 2009; Fry, and Young, 2008; Countinho, 2007; Landine and Stewart, 1998; Soleimani, Nadia, Nagahi and Morteza, 2016; Sony, and Sony, 2015; Keskin, 2014; Gheemi, Farid and Sabkrouh, 2015; Susan, 1995; Fernandez, 1987; Keskin, 2014; Ozturk, 2015; Sony, and Sony, 2015; Chipman. Schrangen. Shalin and Cooke, 2001; Deonaraine, 1998) also indicated that in India there are few studies have conducted on the area of metacognitive strategies with learning styles, thinking styles of different students belongs to different science subject background as compared to studies conducted in abroad and It has also revealed from the above studies that no study has been conducted in the teacher education field with directly taken the variables like Learning Styles of Teacher Trainees and using their Metacognitive Strategies During Training Programme. So, it can be said that there is gap in time, context and also selection of variables. So, investigator has a keen interest to study the relationship of Learning Styles and Metacognitive Strategies of Teacher Trainees and to determine the Learning Styles as positive predictor and contributor for Metacognitive Strategies of Teacher Trainees during their Training Programme.

Keeping on this above discussion and review of related literature the researcher has found the significance of Metacognition as an influenced factor of learning which affects learners' academic performance, cognitive functioning, and personality. In these regards there are many studies have been conducted by the researcher to explore the relationship between metacognition and other cognitive process of learners like learning styles, learning performances, self-efficacy, thinking styles, personality factors.

\section{Objectives of the Study}

The objectives of the present study stated as:

1. To analyze the Learning styles of teacher trainees.

2. To ascertain the use of Metacognitive Strategies of Teacher Trainees.

\section{Hypotheses}

After gone through the previous related researches, the following research hypotheses were formulated

$\mathbf{H}_{1}$. There is significant positive relation between learning styles and Metacognitive Strategies of teacher trainees.

$\square \mathbf{H}_{2}$. Activist Learning style is positively related with the Metacognitive Strategies (planning, monitoring, organizing evaluating) of teacher trainees.

\section{Methodology of the Study}

The purpose of present study aimed to assess the relationship among Learning Styles and Metacognitive Strategies of Pre-service Teacher 
Trainees of Odisha, keeping in view, the nature and objectives of the study the correlational research method was used.

\section{Population and Sample}

All the Teacher Trainees those who are pursuing their secondary teacher training programme from different teacher training institution affiliated to SCERT, Odisha constituted as the population of the present study.

1. Metacognitive Strategy Scale

2. Learning Styles Questionnaire

\section{Data Analysis and Interpretation}

Table 1: Learning Styles and Planning Metacognitive

\begin{tabular}{|c|c|c|c|}
\hline Variables & $\mathbf{N}$ & $\begin{array}{l}\text { Coefficient of } \\
\text { correlation ' } r \text { ' }\end{array}$ & $\begin{array}{l}\text { Significant } \\
\text { Level ( } 2 \text { tailed) }\end{array}$ \\
\hline Planning Vs Activist & & $0.528^{* *}$ & 0.000 \\
\hline Planning Vs Reflector & 120 & $0.561^{* *}$ & 0.000 \\
\hline Planning Vs Theorist & & $0.533^{* *}$ & 0.000 \\
\hline Planning Vs Pragmatist & & $0.529 * *$ & 0.000 \\
\hline $\begin{array}{l}\text { Planning Vs Total } \\
\text { Learning Styles score }\end{array}$ & & $0.640^{* *}$ & 0.000 \\
\hline
\end{tabular}

**significant at 0.01 level of significance.

It is evident from table 1 that the obtained values of coefficient of correlation of Planning dimension of metacognitive strategy and Activist, Reflector, Theorist, Pragmatist and Total Learning Style of Pre-service teacher trainees are (Accordingly $0.528^{* *}, 0.561^{* *}, 0.533^{* *}, 0.529^{* *}, 0.640^{* *}$ ) positively related and significant at level 0.01and 0.05 level of significance. As their $p$ values are less than 0.01 level of significant.

Table 2: Learning Styles and Monitoring Metacognitive

\begin{tabular}{|c|c|c|c|}
\hline Variables & $\mathbf{N}$ & $\begin{array}{l}\text { Coefficient of } \\
\text { correlation ' } r \text { ' }\end{array}$ & $\begin{array}{l}\text { Significant } \\
\text { Level ( } 2 \\
\text { tailed) }\end{array}$ \\
\hline Monitoring Vs Activist & & $0.562^{* *}$ & 0.000 \\
\hline Monitoring Vs Reflector & 120 & $0.616^{* *}$ & 0.000 \\
\hline Monitoring Vs Theorist & & $0.607^{* *}$ & 0.000 \\
\hline $\begin{array}{l}\text { Monitoring Vs } \\
\text { Pragmatist }\end{array}$ & & $0.545^{* *}$ & 0.000 \\
\hline $\begin{array}{l}\text { Monitoring Vs Total } \\
\text { Learning Styles score }\end{array}$ & & $0.690^{* *}$ & 0.000 \\
\hline
\end{tabular}

**significant at 0.01 level of significance.
It is evident from table 2 that the obtained values of coefficient of correlation of Monitoring dimension of metacognitive strategy and Activist, Reflector, Theorist, Pragmatist and Total Learning Style of Pre-service teacher trainees are (Accordingly $0.562^{* *}, 0.616^{* *}, 0.607^{* *}, 0.545^{* *}, 0.690^{* *}$ ) positively related and significant at level 0.01and 0.05 level of significance. As their $\mathrm{p}$ values are less than 0.01 level of significant.

\section{RESULTS AND DISCUSSION}

From the above analysis and interpretation, it can be concluded that learning styles (i.e. Pragmatist, Theorist, Reflector and Activist) of teacher trainees were positively related with their Planning dimension of metacognitive strategy. Results of the present study were supported and correlates directly to the research findings of many studies are Jafarpanah, and Farahian, (2016), investigated that "Significant relationship between learning styles with metacognitive strategy". Abu-Ameerh, (2014) revealed that "Significant positive correlation between the dimensions of learning styles and meta-cognition, learning styles significantly explain and predict all sub-dimensions of meta-cognition." Heidari , and Bahrami, (2012), indicated that "Levels of thinking styles were positively correlated with metacognitive awareness. Moreover, significant positive correlations were found between hierarchical, anarchic, and external styles and metacognitive awareness." Armbruster, Echoles, Brown, (1983), found in their study that "Development of metacognition is related to proficiency in learning". Baker, (2002), indicated that "The control component of Metacognition is related to self-regulation of cognitive efforts, and it Comprises on "planning", "efforts", "evaluating", "remedying", and "testing". Akkoyunlu, Soylu and Shannon, (2008) revealed that "Students' Metacognitive strategies is a valuable skill that helps students become more self-directed learners.

\section{Major Findings}

The main findings drawn from the analysis and interpretation of results. The findings have been given in the following heading.

The four dimensions of metacognitive strategy (i.e. Planning, Organizing, Monitoring, and Evaluating) are positively related with Activist, Reflector, 
Theorist, and Pragmatist Learning Styles of teacher trainees. So, all the teacher trainees having Activist, Reflector, Theorist, and Pragmatist learning styles have strong ability to make planning, Organizing, Monitoring and Evaluation (metacognitive strategies) of any cognitive task in teaching learning context. There is also significant positive relations were found between overall four metacognitive strategy and learning styles overall of teacher trainees. Therefore Activist, Reflector, Theorist, and Pragmatist learning styles are the significant factors of metacognitive strategies.

\section{Educational Implications}

In lieu of main findings and discussion of results the present study has its greatest implications for the planer, policy maker, administrator, teacher and student in the following ways.

\section{Implications for Teachers (both pre-service and in-service)}

In order to know about the learning styles of students and to foster their ability of cognitive execution and regulation like plan, organize, monitor and evaluate the self-works, the teachers must be well trained. In this way the study would help the teachers to develop teaching strategies that would support the desired learning style for students which will contribute and predict their metacognitive strategies.

\section{Implications for Teacher Educators}

There has to be create an environment in training classroom the teacher educators where teacher trainees rely on their own intuitive thought processes to understand their styles of learning which will develop the best practices of metacognitive strategies like planning, organizing, monitoring and evaluating, during training programme and while they develop the lesson plan for practice teaching.

\section{REFERENCES}

Akkoyunlu, B. and Soylu, M. Y. 2008. A Study of Students' Perceptions in a blended learning environment based on different learning styles. Educational Technology $\mathcal{E}$ Society, 11(1): 183-193.

Armbruster, B.B., Echoles, H.C., and Brown, L.A. 1983. The role of metacognition in reading to learn: A developmental perspective. Manuscript submitted for publication.
Baxt, V.S. 1995. Metacognition gets personality: A developmental study of the personality correlates of metacognitive functioning (Doctoral dissertation). Available from ProQuest Dissertations and Theses database. (UMI No. 1434728).

Brown, A.L. 1978. Knowing when, where and how to remember: A problem of metacognition. In: R. Glaser (Ed.) Advances in instructional psychology. Hillsdale, NJ: Erlbaum, pp. 77-165.

Chipman, S.E., Schrangen, J.M. and Shalin, V.L. 2000. Introduction to cognitive task analysis. In: S.E. Chipman, J.M. Schrangen and V.L. Shalin (Eds.), Cognitive task analysis. Malawah, NJ: Lawrence Erlbaum.

Coutinho, S. 2008. Self-efficacy, metacognition, and performance retrieved from http://www.highbeam.com/ doc/1G1178452273.html

Dales, I.Z. and Gaylo, N.D. 2017. Metacognitive strategies: there effects on students' academic achievement and engagement in mathematics. World View of Business Research, 7(2): 55 .

Deonaraine, V.V. 1998. Metacognition: Underline dimensions and relation to cognitive style. (Dissertation Abstract International). Available from ProQuest Dissertations and Theses database. (UMI No. 1434728).

Ghaemi, F. and Sabokrouh, F. 2015. The relationship between personality traits and metacognitive listening strategies among Iranian EFL learners. ELT Voices-International Journal for Teachers of English, 5(2): 11-20.

Honey, P. and Muford, A. 1986 The manual of learning styles, Peter Honey Publications ltd. Ardingly House, 10 Linden Avenue Maidenhead, Barkshire.

Jafarpanah, Z. and Farahian, M. 2016. The relationship between learning styles and metacognitive reading strategy of EFL learners. International Research in Education, 6(1): 47-54

Kesking, K.H. 2014. A path analysis of metacognitive strategies in reading, self-efficacy and task value. International Journal of Social Science and Education, 4(4): 798-805.

Landine, J. and Stewart. 1998. Relationship between metacognition, motivation, locus of control, selfefficacy, and academic achievement. Canadian Journal of Counselling, 33(2): 200-210.

Oxford, R. and Nyikos, M. 1989. Variables affecting choice of language learning strategies by university students. Modern Language Journal, 73: 291-300.

Ozturk, N. 2015. A short review of research on metacognition training with elementary students. Journal of Educational and Industrial studies in the world, 5: 50-60.

Rubin, J. 1975. What the "good language learner" can teach us. TESOL Quarterly, 9: 41-51.

Sawhney, N. and Bansal, S. 2015. Metacognitive awareness of undergraduate students in relation to their academic achievement. The International Journal of Indian Psychology, 3(1): 107-114. 
Sony, S. and Sony, N. 2015. Personality traits of metacognitive functioning among teacher trainee. International Journal of Advance Research and Innovative Ideas in Education, 1(5): 382-390.
Tok, H., Ozgan, H. and Dos, B. 2010. Assessing metacognitive awareness and learning strategies as the positive predictor for success in a distance learning class. Mustafa Kemal University Journal of Social Science Institute, 7(14): 123-134. 
